\title{
The Concept of Prenatal Education Aswaja Annahdliyah's Perspective in Shaping the Character of Early Childhood
}

\author{
Ehwanudin, Mai Zuniati \\ IAIMNU Metro Lampung \\ ehwanudin@gmail.com
}

\begin{abstract}
This article concerns prenatal education, which is still less reacted by educational experts. The younger generation has meanwhile started a shift in determining its potential life partner in this millennial era. The aim of this study is therefore to reveal the concept of prenatal training in Aswaja Annahdliya, in the context of library research, in shaping the character of early childhood. This is specifically a series of activities related to library data collection, reading, notes and research material processing. The primary evidence is based on the idea of Aswaja and the concept of Khittah Nahdlilah. He always uses his way of thinking, not extremist and secondary data from expert opinions on the subject. The conclusion of this study is that the implementation of prenatal education needs to be based on Islamic law, namely Alqur and Hadeith as its main source; the opinions of the four Mahzabs from Maliki, Hanafi, Syafi'i, and Hambali, and of Nahdlatul-based muktabaroh books, as long as they are not contradictory with Alquran and existing traditions. This applies to keeping good old traditions and adopting new, more advantageous traditions.
\end{abstract}

Keywords: Prenatal Education, Aswaja Annahdliyah, Early Childhood Character

(C) 2021 Ehwanudin, Mai Zuniati

This work is licensed under a Creative Commons Attribution-ShareAlike

\section{INTRODUCTION}

In this current millennial era, which affects the development of human culture and civilization, especially the current young generation, in an alarming manner, conditions in families in their respective homes cannot be ignored. As a result, early guidance for children is required, and even prenatal education is required for very important endeavors. Religious education, prenatal education, character, manners, literacy, and arithmetic, as well as the role models of both parents, are especially important in forming basic personality traits and beliefs in early childhood and adulthood.

According to Mufidah $\mathrm{Ch}$, parents hold an important and main role in providing guidance and guidance (both physically and psychologically) to their children in order to prepare future generations who are more qualified as noble 
servants of Allah and as citizens who are morally and socially responsible (Mufidah, t.t.), to become a responsible citizen of Nahdlatul Ulama is a religious movement that aims to participate in building and developing people and communities who fear Allah Subhanahu wa Ta'ala, intelligent, skilled, noble, peaceful, just and prosperous (Abdul Mu'in DZ, t.t.) whose founder is KH Hasyim As'ari (Ehwanudin, 2016) has an understanding of aswaja Anahdliyah which has the teachings of tawazun, tasamuh, ta'adul and amar ma'ruf nahi mungkar (Ehwanudin dkk., 2021), to the development of its intellectual tradition is the Bahsul Masail institution which is guided by the four schools of Maliki, Hanafi, Syafi'i and Hambali as well as the muktabaroh books established by Nahdlatul Ulama (Ahmad Zahro, t.t.) and in the concept of implementing education always adheres to the principles of maintaining the old tradition good and take new and better things, including the concept of prenatal education which has received less response from Islamic education experts.

Previous srtudies on, for example, prenatal education; First) Accordng to Rohma Nur Ichromi 2013 (Rohma Nur Ichromi, tt), which concludes that the concept of prenatal education provides educational stimulation for fetuses that have become babies while in the womb which are carried out consciously by both parents using a) the prayer method, b) worship methods, c) reading and memorizing methods, d) recitation methods e) intructive methods $\mathrm{f}$ ) dialogue methods g) joint activity methods $h$ ) natural conducive methods, and steps for prenatal education that must be surpassed are choosing a future wife according to the advice of the prophet Muhammad SAW. Second) According to M. Ma'ruf's 2017 research, in the process of implementing prenatal education, both parents, who have full responsibility from birth to this world to becoming an adult later greeted by society, this must be done with some the first stage, the selection of a prospective husband/wife, the second in the pregnancy process, and the third is always praying to. Third), according to Amal Fatullah's research, prenatal education should be a fascinating study for Islamic educators today because there is a change in deciding the prospective husband or wife where the child's rights to decide his partner are more important than the rights of the parents, which is a far cry from the practice exemplified by the Prophet and his Companions. There is also the new marriage pattern, namely the origin of marriage via sirri marriage, even though the position of guardian is challenged, for example, by the former chief whose parents served him. When parents are pregnant, they are already aware of the positive and negative effects of education from an Islamic viewpoint, so education done while pregnant is no less necessary. As a result, his parents must maintain emotional security, and Islam prohibits Thalak from leaving his pregnant wife. This implies that prenatal education is important in the context of Islamic education, and that Islamic education experts should pay attention to this issue.

The difference between previous research and the author's research is in the perspective used in examining the concept of prenatal education, specifically in the perspective of Ahlusunah waljama'ah Annahdliyah, which bases its educational pattern on the benefits of maintaining good old traditions while also adopting new, better traditions for the sake of social stability in the unitary state.

\section{METHODOLOGY}

This study is a type of qualitative research, which aims to understand the phenomena experienced by research subjects, such as behavior, perception, 
motivation, action, and so on, holistically, through descriptions in the form of words and language, in a natural special context, using various scientific methods (Lexy j. Moleong, 2011) Focuses on library research, which is a collection of tasks involving the method of gathering library data, reading and taking notes, and analyzing the research material discovered (Mestika Zed, 2004, ). Various literatures, both in libraries and elsewhere, may be used to learn about the data collection process. In this sense, literature includes not only books related to the research subject, but also other published document materials such as journals, newspapers, and other similar publications (Mulyana, Deddy. 2002,)

The primary data source is Aswaja's philosophy of thinking, which is founded on the concept of khittah Nahdlilah, which often thinks in the tollerance way, rather than the extremist. In all fields, including psychological, medical, and Islamic ideas, the reason for using this basic definition has a more moderate explanation. Secondary data sources, on the other hand, are concrete data sources such as interpretations, documents, journals, magazines, or scientific works (research) related to the field of analysis.

Among the books included in this secondary source is a book by Abdullah Nasih Ulwan entitled "Pendidikan Anak dalam Islam". The book by Samsul Munir Amin is entitled "Menyiapkan Masa Depan Anak Secara Islami". Aliah B. Purwakania Hasan's book, "Psikologi Perkembangan Islami, Menyingkap Rentang KehidupanManusia dari Prakelahiran hingga Pascakematian", Revealing the Span of Human Life from Pre-Birth to Post-Death". A book by Abdul Mun'im Ibrahim, "Mendidik Anak Perempuan". Husain Mazhahiri's book, "Pintar Mendidik Anak." As well as other books that support the themes discussed. For data collection techniques, descriptive qualitative research emphasizes data analysis on existing data sources. In accordance with the type of data used in this study is a research library. Namely by looking for sources obtained from various books and other writings by relying on existing theories to be interpreted more clearly and deeply to produce theses and anti-theses that are generated from primary and secondary data sources, through literature research. (library research), namely by browsing books or writings (Abdurrahman Soejono, t.t.),

The data analysis of this research is descriptive qualitative because it is not in the form of numbers arranged in a broad theme. In analyzing the data after being collected the researcher uses the following methods; (Sutrisno Hadi, t.t.) Inductive method, is used when data that has similar elements are found then from there general conclusions are drawn. b) Deductive Method, used in reverse, namely the existing general understanding, looking for data that can strengthen it and c) Descriptive Method, used to describe everything related to the subject in a systematic, factual and accurate manner regarding the factors / characteristics as well as the relationship between the two investigated phenomena. In the end, a general conclusion was drawn which originally came from specific data about the object of the problem being discussed. 


\section{RESULTS AND DISCUSSION}

Education in the philosophy of Islam is applied constantly and continuously from the time in the womb to the fullest. In other terms, some refer to it as lifelong education. It is sometimes referred to as continuing education (M. Makagiansar, t.t.)

Prenatal education, according to Ramayulis, is education before childbirth. This period is distinguished by, among other things (Ramayulis, 2008):

1) Match selection phase; namely preparation for someone who has grown up to face a new life, namely having a family. The education that an adult must have is a matter of choosing the right mate. Because this greatly affects the happiness of the household in the future both in this world and in the hereafter. According to him, choosing a mate, the requirements and the criteria are divided into two groups, namely: general criteria and specific (subjective) criteria. General requirements should be that the mate chosen is an adult so that you don't experience difficulties in having a family and the special requirements are of course according to each person's taste But the most important requirement is to love each other.

In Islam, choosing a mate in marriage, there are several rules and laws for applicants and those who are proposed, if this is done, the marriage will be at the peak of harmony, love and harmony as stated in Islamic teachings. As the Prophet said: 1) "There will be no love for each other because of Allah SWT., Except the more important between the two, namely for the one who is greater in love for one another" (HR. Bukhari). 2).(Hussein Bahressj, t.t.), "Whoever marries a woman for her glory, God will not add to her except disgrace; whoever marries for her money, God will not add to her except poverty. If a man marries because of his status, God can only add modesty to him. And whoever marries a woman solely for the purpose of preserving his eyesight, penis, or family relations, God will bless that person on that woman and bless that woman on him." ( HR. Thabrani).(Abdullah Nasch Ulwan, t.t.), 3)" This world is jewelry, the best jewelry is a shalehah woman. (HR. Muslim).(Hussein Bahressj, t.t.), 4) Select for your sperms (prospective wives) all of you and marry all of you people of equal rank. (HR. Daruquthni dan Ibnu Majah).(Abdullah Nasch Ulwan, t.t.), 5) There is nothing useful for a Muslim after taqwa to Allah that is better for him than a shalehah wife who when her husband commands her she obeys, when her husband looks at her then he pleases her; when the husband takes turns then he obeys it, and when the husband erpergian from him then he takes care of himself and property (her husband) ( HR. Ibnu Majah). 6) "Stay away from green grass that is in a dirty place. They asked, what is the meaning of green grass that is in the dirty place, $\mathrm{O}$ Messenger of Allah? He replied, that is a very beautiful woman who grows up in a bad place" (HR. Daruquthni). 7)" Do not marry relatives, because you will be able to bring down children who are physically weak and stupid.(Abdullah Nasch Ulwan, t.t.)" 8)" Look for women who are far away, and do not look for women who are close (who are weak in body and weak in brain "). 9) "Marry you all girls. Because they are sweeter in speech, more childbearing, less demanding and deceitful and prefer convenience." (HR. Ibnu Majah dan Baihaqi)(Abdullah Nasch Ulwan, t.t.) 10)" Marry any fertile woman who has given birth to a large number of children and is full of love. And I truly want to multiply the number of people with you all." (HR. Abu Dawud, Nasai dan Al Hikam). 
Based on the explanation of the hadith above, it can be concluded that some requirements for choosing a wife are as follows: First, On the basis of love and affection between the two prospective brides, Second, the choice of women is preferred because of her religion (sholihah) in order to receive blessings from Allah SWT. Because people who choose other than the strength of faith will get humiliation later. Third, the same degree as the bride, in this case the degree of religion. Fourth, Women who live in a good environment. Fifth, Women who are far from the family lineage because they can give birth to children who are physically weak and stupid. Sixth, Women who are virgin and fertile (can give birth).

In contrast to the selection of a prospective husband based on the explanation of the hadith of the Prophet is not as much as the explanation in the selection of a prospective wife, one of them is as follows: "If you are all visited by someone who is great and morals you are pleased, then marry him, if you do not do it, then it will be slander on this earth and destruction will spread. " (HR. Tirmidhi).

The origin of the implementation of children's education can not be separated from the purpose of a marriage, which is to carry out the sunnah of the Prophet Muhammad SAW, get descendants who can continue his message, a place to sow the seeds of faith, give birth to a healthy family and fulfill the encouragement of security, prosperity, and sakinah, full of mawaddah wa rahmah. Therefore, the selection of a partner before marriage is also the main focus in planning the child's education. If wrong in choosing a partner will bring the wrath and hatred of Allah SWT and make people humiliated in this world and the hereafter

In reality there are men who crave rich women, albeit less beautiful. There are those who desire beautiful women, even though they are poor and not rich and their morals are less than perfect. There are those who desire rich, beautiful women, good morals, good offspring, but what almost all these men desire is something that is impossible for them to get. But a man should try to get women who are religious, especially worship, even if other aspects are less appropriate. So in the concept of the teachings of ahlu sunnah waljama'ah Annahdliyah for the basis of thinking about the choice of a mate can be applied by choosing a moderate mindset.

As for the advice in the hadith of the Prophet to take the wife of a pious person, as explained by Nashih Ulwan, for the following reasons; couples who set religion as the basis of choice, will not be matched by wealth, lineage and beauty that are temporary, while religion is eternal in this life and the hereafter.(Baihaqi AK, t.t.)

The threat of Rasulullah SAW that people who choose glory as the basis of their choice will be humiliated. And when property becomes a platform he will feel deprived. And if the offspring he chooses is the main thing he will always languish.

Thus, in the preparation of education, the poem of choosing a mate must begin. The hadith revealed by the Prophet SAW does not merely explain the alternative of choosing a wife or merely advocates choosing a woman who is only religious but more than that, for future generations, through educational efforts. Descendants born and raised and educated by a devout wife will most likely become righteous children after adulthood. If it is possible to choose a woman who has everything, namely beauty, wealth, lineage and religion, which are all good, it would be very ideal and gratifying if you cannot choose a balanced one of the four options. But in reality it shows that it is very difficult to get such a perfect woman. That is, among other reasons, why Rasulullah SAW gave a scale of priority and chose religious women who are devout in worship. The Prophet SAW also reminded women to choose a husband who is also religious. 
1) Marriage phase

According to Abdullah Nashih Ulwan quoted by Ramayulis that the problem of marriage consists of two aspects, namely marriage as a human nature, marriage as a social benefit.(Ramayulis, t.t.) As for the Islamic syari'at related to the recommendation of marriage / marriage, it is described in the Qur'an and the hadith of the Prophet including: 1) "Whoever is able to get married, but he is not married, he is not in my group" (HR. Thabrani dan Baihaki). 2) "And among the signs of His power is that He created for you wives of your own kind so that you tend to feel at peace with him, and He made between you a sense of love. Indeed in that are signs for a people who think. " (QS. Al-Rum: 21). 3) "Allah has made for you a wife a wife of your own kind and made for you from your wife your children and grandchildren." (QS. AnNahl:72). 4) "O young men, whoever of you is able to get married, then get married, because the marriage will be able to better maintain the view and be able to better maintain the genitals. And whoever is not able to get married then he should fast because in fact fasting will restrain lust. " (HR. Jama'ah).

From the explanation of the naqli argument above, it can be concluded that matters related to marriage include: 1) Marriage is the Sunnah of the Prophet Muhammad, 2) Marriage is to create peace and affection, 3) Marriage is to have offspring. 4) Marriage to maintain the view and keep the genitals from immorality.

The process of marriage after the candidate is selected, the marriage is held, and then the marriage is carried out with his al-urusy walimat. What is interesting in marriage is that in Islam, the marriage sermon is read before the consent of the qabul. The marriage sermon contains educational values, namely: increasing faith and charity, good association between husband and wife, household harmony, maintaining friendship and introspection in every action and behavior in social life.

Furthermore, all these processes are completed, then the husband and wife are legal to have sexual intercourse. However, before having sexual intercourse, the circumcised recited the following prayer: "In the name of Allah, O Allah, keep the devil away from us and keep the devil away from the child that (maybe) You have given us." (H.R. Muttafaq 'Alaih). From the prayer above, there is an element of education that through this prayer the prospective parents have educated themselves and their future children to always be close to Allah SWT with high hopes that their descendants will become pious and sholihah servants.

\section{2) Pregnancy Phase}

Among the coveted goals of a household is to have children, therefore a wife really hopes that she can give birth to a child. As a sign a wife will have a child is through the process of pregnancy for about nine months.

In order to have a child, Islam teaches to always pray to God by reciting prayers like the prophet Ibrahim; "My God, give me a righteous child." (QS. As Shafat ayat 100).

Furthermore, after the conception period, the educational process can be done, although it is still indirect (indirect education). This phase is one step further than the first. The post-conception phase is also called the time of pregnancy. For 
the pregnancy phase in the womb of approximately nine months to ten days, there is also less or more than that. Although this phase is relatively shorter than the other phases, but in this period both parents have made efforts with prayer to be kept away from the temptations of the devil to the fetus that will be conceived so that it gives a very important meaning to the process of human character formation. (Ehwanudin dkk., 2021) then later in the period of birth to reach an early age.

Opinion of Imam Bawani, (Imam Bawani, t.t.) The phase of pregnancy has several stages. 1), nuthfah stage. At this stage the prospective child is still in the form of sperm fluid and egg cells. This lasted for forty days. 2), the stage of alaqah namely; After the age of 80 days, nuthfah develops like a thick blood clot and depends on the wall of the mother's uterus. 3), Mudghah stage. After that, at about 120 days old, the blood clot had developed into a lump of flesh. At that time the fetus is ready to receive the breath of the spirit from the angel messenger of God Almighty.

Although in the Qur'an and Hadith of the Prophet SAW does not explain in real and detail about the educational process contained in the event, but some opinions of scholars in Islam especially in the understanding of ahlusunah wal jama'ah Annahdliyah have some traditions to implement the education of children in the womb through the recitation of Qur'anic verses such as the letter of Joseph and the letter of Mary in congregation by gathering the surrounding neighbors is intended for the safety of the unborn child who has been 120 days old or often referred to in a three-monthly term and ends with a meal together for the congregation that are present. Then the tradition is to invite the congregation around when the mother's pregnancy reaches seven months or often called seven months by reciting the sentences of tayibah, remembrance and prayer before the birth of the child later.

Furthermore, looking at it from the aspect of tradition that has an element of education, there are at least three factors to be discussed, among others:

First; it can be believed that the phase in the womb must begin from the existence of life (al hayat). The belief is based on a fact, which is that development has taken place. Starting from nuthfah, alaqah and Mudghah, it means that nuthfah itself already contains life (al hayat). Without the element of life (al hayat) there can be no development, but it must be understood, that life (al hayat) in that phase is still biological.

Second: based on the explanation above, that is, after the form of a lump of flesh (mudhgah), Allah SWT sent an angel to blow the spirit to him. From here is the starting point and at the same time a beginning of the movement of the motor of human psychic life. Meaning at that time, the life of the fetus is biological, it already has an aspect of psychological life. Then, in the fourth month, the fetal heart begins to work, so that its vibrations can be monitored with a shetescope. Since then, the fetus has been able to move, which the longer the stronger the movement. On the other hand, with the presence of the spirit or soul, the fetus can begin to perform tasks such as feeling, thinking, remembering, imagining, dreaming and so on. All of that certainly shows the existence of his soul life.

In other studies, the development or existence of a psychic life can also be proven by associating the joy and inner suffering of the mother with the unborn baby. Happiness, agility, calm that is always shown by a mother who is pregnant, is often reflected in her baby later after birth. Similarly, on the other hand, sadness, 
depression, envy, pride and so on will not be inherited by the baby later after birth to an early age.

Third: there is one important aspect for the fetus at the time of conception, namely the religious aspect. Because the religious instincts of each individual have been embedded so far, even before his birth in the real world. This is in accordance with what is described in the hadith; "The words of the Prophet SAW; Indeed, you were created through the womb of your mother (womb), 40 days in the form of nthfah, after from nuthfah changed into alaqah, for 40 days, then from alaqah into mudghah for 40 days. Then God sent an angel and commanded the angels four things. And Allah spoke to the angels. Write down his knowledge (man), his sustenance, his death and his misfortune, then the angel blew the spirit upon him (H.R. Bukhari dan Muslim).

In the explanation of the Hadith above by nature, human beings are religious beings. Because before the spirit of sex was blown, he had already acknowledged God as his God, it is said to be religious because instinctively, human beings in essence always acknowledge the existence of the One True God. Therefore, it means that human beings have the potential readiness to recognize and acknowledge the existence of God. This period of pregnancy is very important, because it is the beginning of life. In the womb every fetus is protected from all the influences of external conditions except those that can reach through the pregnant mother. That sense of security and protection will never be found by a child after he is born.

As for the process of prenatal education, according to Ramayulius (Ramayulis , t.t.) done indirectly (indirect) as follows:

a. A pregnant mother should pray for her child. The prenatal child must be prayed for by his parents, because every Muslim believes that Allah SWT is the Almighty and the prenatal child is the trust of Allah SWT entrusted to him. He did not participate with God in the effort of the creation of his child, except for the cause and he was unable to do anything but maintain the physical and spiritual health of his wife. With the care, it is hoped that the child in the womb will be physically and spiritually healthy. So if the prenatal child is merely the creation of Allah Almighty, then he is the Almighty to make the prenatal child righteous, or vice versa. If that is the case, then praying for a child to be made good and righteous is a logical and sensible thing.

b. According to Al Ghazali, the method of training children is the most important and foremost thing. A child is a trust for both parents. His pure heart is a very precious jewel. If he is trained to do good then he will grow into a good and happy child in this world and the hereafter. But on the other hand, if he is allowed to do evil and left alone, then he is like an animal and his life will be miserable both in this world and in the hereafter.(Al Ghazali, t.t.)

c. The mother must always take care of herself to keep eating halal food and drink. On the other hand, if he often eats/drinks that which is haram then his prayers will not be answered. Furthermore, if he intends for his prenatal child to be born and mature, then he must take care that the food and drink given to his child must be good and halal. The halal food and drink are given to the prenatal child, of course, through the pregnant 
mother. The words of Allah SWT which means: "Eat the sustenance that Allah has given you that is lawful and good". (QS. Al-Maidah: 88).

d. Teach children honestly. Every parent must be serious in their efforts to educate their prenatal children. Sincerity means that all actions and activities, especially efforts to educate prenatal children, are undertaken with the intention of drawing closer to God and obeying Him, not with the intention of receiving selfishness or reward from the child later. In other words, educating prenatal children should be done with the intention of worshiping, enslaving oneself to Allah SWT, and maintaining one's faith in Allah SWT.

e. Cater for the wife's needs. Husbands must take care of their pregnant wives' needs, particularly in the early days after their birth. At the time, the wife was plagued by peculiar impulses that came out of nowhere. A husband who does not realize this will be taken aback when he learns his wife has changed drastically. The wife has a variety of criteria that must be met.

1) Requires attention,

2) Requires affection,

3) Additional dietary requirements,

4) The prerequisite to grant a strange will,

5) The need for serenity,

6) Needs hope,

7) The need for upkeep,

8) The need to be beautiful.

f. Often, Taqarraub (draw closer) to Allah SWT by obligatory and sunnah worship. Your soul is more clean and pure, and it is closer to Allah SWT, if your Mother/Father is attentive in worship. Allah SWT is a Most Holy Being who can only be approached with a pure heart. The innocence of the Mother/Father who receives God's grace will radiate to the infant in her womb's soul.

g. Both parents are of noble character. Parental morals have a great influence and become a positive stimulus for the unborn child. The noble morals that should be the decoration of both parents are;

1) Compassion

2) Polite and gentle

3) Forgiving, and

4) Reconcile with family and neighbors

According to Zakiyah Darajat's (Zakiah Daradjat, t.t.) (view, the educational procedure carried out during the pregnancy period is not specifically for the fetus in the womb. However, all parents' actions have a direct effect on the fetus in the womb. At the time, psychological interaction between parents, especially the mother, and that discipline was referred to as education.

So it can be understood that at this stage of pregnancy the fetus is very closely related to the mother. So, the mother is obliged to take care of the womb, among others; 1) choose to eat nutritious food; (2) avoid strong movements and collisions, 3) do not get angry often but be gentle, 4) stay away from alcoholic drinks, smoke and various types of food that are forbidden by Allah SWT and 5) protect the uterus so that it does not get sick or infected. With such endeavors, God 
willing, maintenance efforts will make the fetus a child who is physically and mentally healthy after birth to early childhood and even to adulthood, as a very large basis for the process of human education.

The educational process must be started from the time the child is in the womb (prenatal education), which is the period of child development before birth and is still in the womb of the mother. The period of development of the child since the conception period (meeting of the sperm and ovum). This process develops until the child is born into the world which takes approximately nine months.

\section{CONCLUSION}

Based on the above research, it can be concluded that in the implementation of the prenatal education process must be based on Islamic law, namely the Qur'an and hadith as the main basis, then based on the opinion of the four schools of Maliki, Hanafi, Syafi'i and Hambali and the books muktabaroh set by Nahdlatul and traditions that exists as long as it does not contradict the Qur'an and the hadith of the Prophet. It uses the principle of maintaining good old traditions and taking new traditions that are more beneficial.

Thus in the process of implementing prenatal education starts from both parents who have full responsibility starting from the election of a prospective husband/wife, second in the process of pregnancy and third always pray to the child in the womb until he is born into this world, early childhood to become a person who will grow up in society, this should be guided by the concept of educational thinking developed in the understanding of Annahdliyah aswaja.

\section{ACKNOWLEDGEMENT}

I would like to thank all those who have supported and assisted our research. Do not forget to also thank the Journal of Childhood Development IAIMNU Metro Lampung for publishing our research in the form of scientific articles.

\section{REFERENCES}

Abdul Mu'in DZ. (t.t.). Piagam Perjuanga Kebangsaan, Jakarta, Setjen PBNU On-line Tahun 2011.

Abdullah Nasch Ulwan. (t.t.). Al- Ausatah oleh Abdullah Nasch Ulwan, Pendidikan Anak Dalam Islam, penerjemah, Jamaluddin Miri, Lc. Judul Asli Tarbiyatul Aulad fil Islam ( Jakarta: Pustaka Amini tth),.

Abdurrahman Soejono,. (t.t.). Metode Penelitian suatu Pemikiran dan penerapannya, (Jakarta: Rineka Cipta, 1999), hlm 19.

Ahmad Zahro. (t.t.). Tradisi Intelektual NU (Lajnah Bahsu Masail 1926-1999), Yogjakarta, LKiS, 2004.

Al Ghazali. (t.t.). Ihya' Ulumuddin, Beirut tt.

Baihaqi AK. (t.t.). Pendidikan Islam Dalam Rumah Tangga, ( Jakarta: Kalam Mulia, th) h. 104. 
Ehwanudin, E. (2016). TOKOH PROKLAMATOR NAHDLATUL ULAMA (STUDI HISTORIS BERDIRINYA JAMâ? IYYAH NAHDLATUL ULAMA). Fikri: Jurnal Kajian Agama, Sosial dan Budaya, 1(2), 447-468.

Ehwanudin, E., Arifin, M. Z., Mispani, M., Asnawi, H. S., \& Zaini, M. (2021). IMPLEMENTATION OF CHARACTER DEVELOPMENT THROUGH ISTIGHOSAH HABITATING IN THE INSTITUT AGAMA ISLAM MA'ARIF NU (IAIMNU) METRO LAMPUNG. Journal of Contemporary Islamic Education, 1(1), 57-66.

Hussein Bahressj,. (t.t.). Al Jami'us Shahih Bukhari Muslim, ( Surabaya: CV. Karya Utama) h. 164.

Imam Bawani. (t.t.). Ilmu Jiwa perkembangan Dalam Kontek Pendidikan Islam.

Lexy j. Moleong, Metode Penelitian Kualitatif, (Bandung, PT Remaja Offset Rosda Karya, 2011), hlm. 6. (t.t.).

M. Makagiansar,. (t.t.). Continuing Education ini Asia and the Pasific, (Bangkok Unisco Principal Press, 1987. Hlm.2.

Mestika Zed, 2004. (t.t.). Metode Penelitian Kepustakaan, (Jakarta: Yayasan Obor Jakarta: 2004), Hlm, 3.

Mufidah. (t.t.). Psikologi keluarag Islam Berwawasan Gender, (Malang; UIN Maliki Prees, 2013).

Mulyana, Deddy. 2002. (t.t.). Metodologi Penelitian Kualitatif. (Bandung: PT Remaja Rosdakarya), Hlm, 195.

Ramayulis ,. (t.t.). Ilmu Pendidikan Islam, (Jakarta: Kalam Mulia, 2008).

Sutrisno Hadi,. (t.t.). Metodologi Research, (Yogyakarta: Yayasan Penerbitan Fakultas Psikologi UGM, 1987), 36-42.62Ibid, 19.

Zakiah Daradjat,. (t.t.). Problematika Remaja di Indonesia, Jakarta: Bulan Bintang, tth. 